\title{
KERAGAMAN LAMUN SEBAGAI POTENSI PAKAN Dugong dugon DI TELUK LAMTENG, KABUPATEN ACEH BESAR
}

\section{SEAGRASS DIVERSITY AS THE FEED POTENTIAL OF Dugong dugon IN LAMTENG BAY, ACEH BESAR REGENCY}

\author{
Chitra Octavina ${ }^{1,2,3 *}$, M. Rizki Fazillah ${ }^{1}$, Maria Ulfah ${ }^{1,2,3}$, \\ Syahrul Purnawan ${ }^{1,3}$, \& Adli Waliul Perdana ${ }^{1,3}$ \\ ${ }^{1}$ Program Studi Ilmu Kelautan, FKP-UNSYIAH, Aceh, 23111, Indonesia \\ ${ }^{2}$ Laboratorium Biologi Laut, FKP-UNSYIAH, Aceh, 23111, Indonesia \\ ${ }^{3}$ Pusat Studi Kelautan dan Perikanan, FKP-UNSYIAH, Aceh, 23111, Indonesia \\ *E-mail: chitraoctavina@unsyiah.ac.id
}

\begin{abstract}
Lamteng Bay has a very large ecosystem potential. The potential of this large seagrass also supports the abundance of fisheries resources in the area. This study aims to determine the diversity of seagrasses. This research was conducted in December 2018, where the determination of observation stations using the purposive sampling method is based on observations covering the area contained a pier, both small and large docks. The data analysis used is the percentage of seagrass cover $(C)$, density of seagrass species $(D i)$, and seagrass diversity $\left(H^{\prime}\right)$, and to see indicators of the presence of feeding trail left by dugongs and suspecting seagrass preferences which is a favorite dugong as food. The results showed that the composition of seagrass species found in Lamteng Bay waters consisted of three species (Cymodocea serrulata, Halodule pinifolia, Halophila ovalis). The highest seagrass cover by $\mathrm{H}$. pinifolia species was $67.84 \%$, followed by $C$. serrulata $44.79 \%$ and the lowest was $H$. ovalis species $2.21 \%$. As a whole station, $H$. pinifolia species have a higher density value compared to the two other seagrass species with values ranging from 55-316 ind/ $\mathrm{m}^{2}$. Seagrass diversity is relatively low with values ranging from 0-0.9. The three species of seagrass found were a source of food for the Dugong dugon which was included in his favorite seagrass preference category.
\end{abstract}

Keywords: diversity of seagrass, Dugong dugon, feed source, Lamteng Bay

\begin{abstract}
ABSTRAK
Teluk Lamteng memiliki potensi ekosistem lamun yang sangat besar. Potensi lamun yang besar ini turut menyokong kelimpahan sumberdaya perikanan di daerah tersebut. Penelitian ini bertujuan untuk mengetahui keragaman lamun. Penelitian ini dilaksanakan pada bulan Desember 2018, dimana penentuan stasiun pengamatan menggunakan metode purposive sampling yaitu berdasarkan observasi mencakup area yang terdapat dermaga, baik dermaga kecil maupun dermaga besar. Analisis data yang digunakan yaitu persentase tutupan lamun (C), kerapatan jenis lamun (Di), keanekaragaman lamun $\left(\mathrm{H}^{\prime}\right)$, serta indikator keberadaan dugong yaitu dengan melakukan survei feeding trail yang ditinggalkan oleh dugong dan menduga preferensi lamun yang menjadi favorit dugong sebagai makanannya. Hasil penelitian menunjukkan bahwa komposisi jenis lamun yang ditemukan di perairan Teluk Lamteng terdiri dari tiga spesies yaitu Cymodocea serrulata, Halodule pinifolia dan Halophila ovalis. Penutupan lamun tertinggi oleh spesies $H$. pinifolia adalah $67,84 \%$, selanjutnya diikuti $C$. serrulata sebesar $44,79 \%$ dan paling rendah yaitu spesies $H$. ovalis dengan angka $2,21 \%$. Secara keseluruhan stasiun, spesies $H$. pinifolia memiliki nilai kerapatan yang lebih tinggi dibandingkan dengan kedua spesies lamun lainnya, yaitu antara 55-316 ind $/ \mathrm{m}^{2}$. Keanekaragaman lamun tergolong rendah dengan nilai berkisar antara 0-0,9. Ketiga spesies lamun yang ditemukan merupakan sumber pakan bagi $D$. dugon yang termasuk dalam kategori preferensi lamun kesukaannya.
\end{abstract}

Kata Kunci: Dugong dugon, keragaman lamun, sumber pakan, Teluk Lamteng 


\section{PENDAHULUAN}

Kabupaten Aceh Besar merupakan wilayah yang terletak di ujung utara Provinsi Aceh dengan panjang garis pantai mencapai $344 \mathrm{~km}$. Wilayah tersebut kaya akan keanekaragaman hayati (Aceh Besar Dalam Angka, 2011) dan salah satunya adalah lamun. Ekosistem lamun dapat ditemukan di perairan Lamteng, Kabupaten Aceh Besar. Lamun merupakan tumbuhan berbunga (Angiospermae) yang hidup terendam dalam kolom air dan berkembang dengan baik di perairan laut dangkal maupun estuari. Indonesia memiliki 13 spesies lamun yaitu Cymodocea rotundata, C. serrulata, Enhalus acoroides, $H$. pinifolia, $H$. uninervis, Halophila decipiens, H. minor, H. ovalis, $H$. spinulosa, H. sulawesii, Syringodium isoetifolium, T. hemprichii dan T. ciliatum (Kuo, 2007).

Menurut Katwijk et al. (2016), ekosistem lamun memiliki peran penting dalam ekologi kawasan pesisir yaitu sebagai spawning, nursery dan feeding ground dari berbagai biota laut seperti penyu hijau, dugong, ikan, ekinodermata dan gastropoda. Duarte et al., (2013); Hernawan et al. (2017); Nordlund (2018) menjelaskan bahwa informasi mengenai kondisi padang lamun menjadi kebutuhan yang mendasar dalam pengelolaan ekosistem pesisir di Indonesia. Lamun merupakan ekosistem penting yang menunjang kehidupan beragam jenis makhluk hidup, sekaligus sebagai lumbung protein bagi makhluk hidup. Namun demikian, ekosistem tersebut rentan terhadap ancaman kerusakan baik akibat manusia maupun faktor alam.

Juraij (2014) menyatakan bahwa lamun merupakan salah satu feeding ground bagi dugong. Jejak makan atau feeding trail yang ditinggalkan oleh dugong dapat dijadikan indikator keberadaannya. Kehadiran jenis lamun yang menjadi makanan favorit dugong juga dapat menjadi indikator keberadaan dugong di suatu perairan. Menurut Tol et al. (2016); Hashim et al.,
(2017); Dewi et al. (2018), bahwa dugong mengkonsumsi lamun sebagai makanan utamanya. Preferensi pakan dugong terhadap lamun bergantung pada ketersediaan jenis lamun di ekosistem tersebut.

Dugong merupakan jenis mamalia laut yang masuk dalam ordo Sirenia. Organisme ini dilaporkan dapat dijumpai di wilayah perairan Indonesia, walaupun dengan frekuensi yang relatif rendah. Rendahnya perjumpaan dengan dugong di wilayah perairan mengakibatkan statusnya tercatat dalam red list IUCN (International Union for Conservation of Nature and Natural Resources). Langkanya dugong dapat disebabkan oleh beberapa faktor, diantaranya reproduksi, perburuan oleh manusia, dan kondisi habitat yang terancam rusak (Dewi et al., 2018).

Hasil survei identifikasi dan inventarisasi penyu dan dugong di perairan Aceh Besar pada tahun 2017 yang dilakukan oleh Yayasan Lamjabat, Lamteng termasuk dalam kawasan ruaya dugong yang sering terlihat. Kajian keragaman jenis lamun pada kawasan ruaya $D$. dugon belum pernah dikaji di Aceh dan hanya sedikit yang pernah dilaporkan di Indonesia. Oleh karena itu, penelitian ini perlu dilakukan untuk mengetahui keragaman lamun pada area ruaya $D$. dugon, sebagai upaya mendukung konservasi lamun dan $D$. dugon di Indonesia.

Tujuan dari penelitian ini adalah untuk mengetahui keragaman lamun melalui pendekatan komposisi jenis, tutupan, kerapatan dan keanekaragaman serta parameter fisika kimia perairan yang berhubungan dengan keberadaan lamun. Selain itu juga untuk menduga preferensi pakan D. dugon pada Kawasan Konservasi Perairan Daerah Teluk Lamteng, Kabupaten Aceh Besar.

\section{METODE PENELITIAN}

\subsection{Waktu dan Lokasi Penelitian}

Penelitian ini dilaksanakan pada bulan Desember 2018 di perairan Teluk 
Lamteng, Kecamatan Pulo Aceh, Kabupaten Aceh Besar. Kawasan observasi mencakup area yang terdapat dermaga, baik dermaga kecil maupun besar. Secara geografis lokasi penelitian terletak pada titik koordinat sebagaimana tercantum pada Figure 1.

\subsubsection{Penentuan Titik Stasiun}

Stasiun pengamatan ditentukan dengan metode purposive sampling yaitu berdasarkan kemudahan akses dan keberadaan dermaga. Penentuan titik stasiun direkam menggunakan GPS (Global Positioning Sistem). Stasiun 1 terletak di bagian selatan dari dermaga kecil, sedangkan stasiun 2 terletak di antara dermaga besar dengan dermaga kecil dan stasiun 3 terletak di bagian utara dermaga besar.

\subsubsection{Pengambilan Data Lamun}

Pengambilan sampel lamun dilakukan dengan metode simple random (English et al., 1997) yaitu menggunakan transek garis (line transect) dengan teknik sampling kuadrat. Sebanyak 3 (tiga) transek garis dibentangkan tegak lurus dari pinggir pantai menuju tubir, dengan jarak antara transek garis yaitu $25 \mathrm{~m}$. Pada setiap transek garis, ekosistem lamun diamati dengan bantuan transek kuadrat $50 \mathrm{~cm}$ x $50 \mathrm{~cm}$ yang dimulai dari titik $0 \mathrm{~m}$ sampai dengan $100 \mathrm{~m}$ dan diulangi setiap $10 \mathrm{~m}$. Jarak pandang pengamat disisi kiri dan kanan rolmeter adalah $2 \mathrm{~m}$. Data yang diambil adalah jenis lamun, kerapatan lamun, dan penutupan lamun. Jenis-jenis lamun yang terdapat pada setiap plot diamati dan dicatat (Unsworth et al., 2019).

\subsubsection{Pengambilan Data Indikator Keberadaan Dugong}

Metode yang digunakan untuk melihat indikator keberadaan dugong yaitu dengan melakukan survei keberadaan jejak makan atau feeding trail yang ditinggalkan oleh dugong dan menduga preferensi lamun yang menjadi favorit dugong sebagai makanannya dengan keragaman jenis lamun pada lokasi penelitian (Juraij et al., 2014).

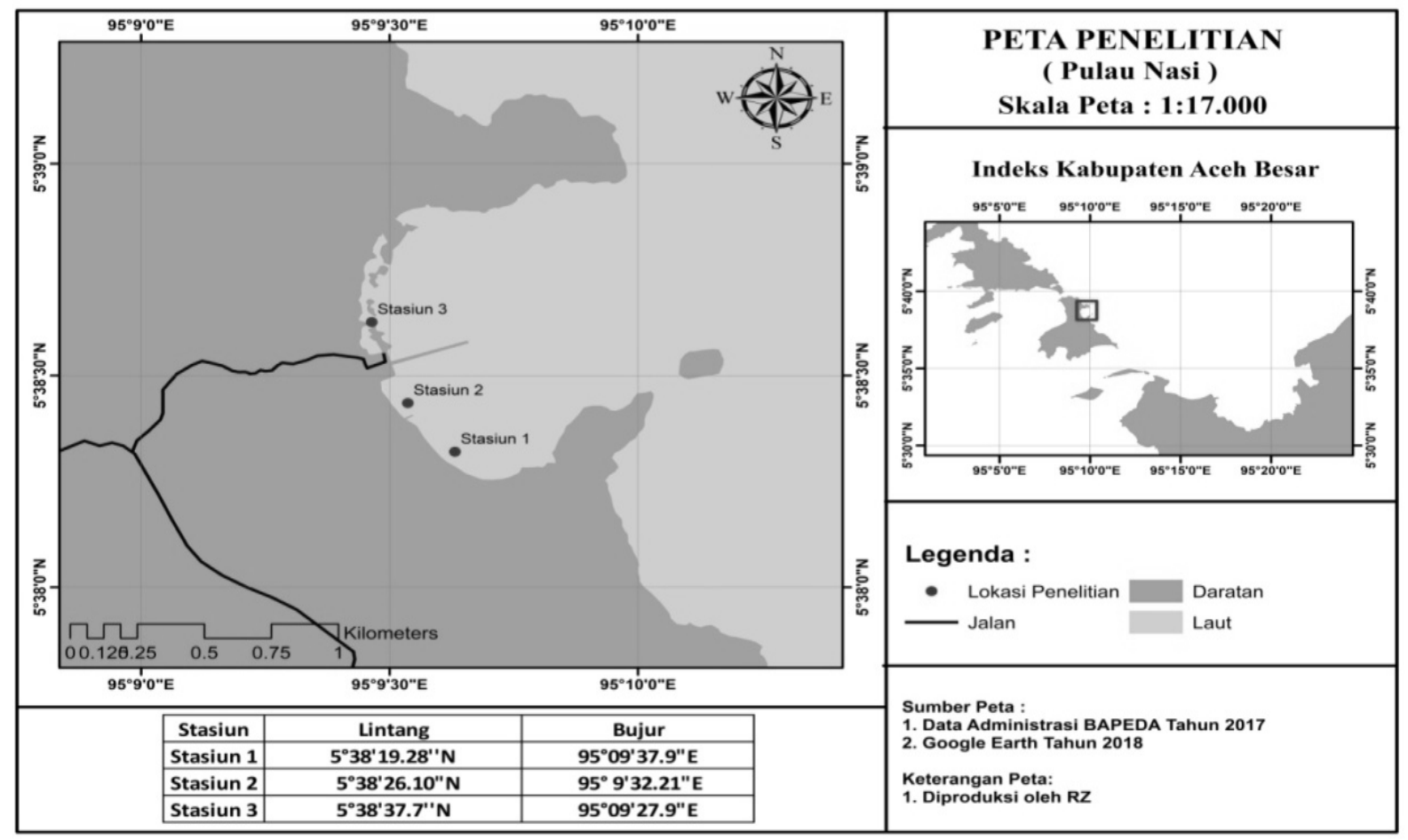

Figure 1. Research location in Lamteng Bay. 


\subsubsection{Pengambilan Data Parameter Lingkungan}

Parameter lingkungan perairan yang diamati meliputi: suhu, salinitas, kecerahan dan kecepatan arus. Data parameter diambil di setiap stasiun dan diukur secara in situ dengan 3 kali ulangan. Selain itu dilakukan pengambilan sampel sedimen menggunakan metode core dengan pipa paralon PVC berdiameter $5 \mathrm{~cm}$ pada titik yang telah ditentukan, yaitu sedimen diambil pada kedalaman penetrasi akar $30 \mathrm{~cm}$. Setelah dilakukan pengambilan, sampel dimasukkan ke dalam plastik yang telah diberi label keterangan (Yunitha et al., 2014). Analisis sampel substrat menggunakan metode pipet (Salim et al., 2017) dilakukan di Laboratorium Kimia Tanah Fakultas Pertanian Universitas Syiah Kuala.

\subsection{Analisis Data}

\subsubsection{Identifikasi Jenis Lamun}

Identifikasi jenis lamun dilakukan dengan cara mencocokkan data-data di lapangan seperti bentuk daun, bunga, rimpang (rhizoma) dan akar pada lamun dengan mengacu pada kunci identifikasi lamun di Indonesia (Den Hartog, 1970).

\subsubsection{Tutupan Lamun}

Luas area penutupan jenis lamun tertentu diketahui dengan membandingkan luas total area penutupan seluruh jenis lamun (Saito \& Atobe, 1970) dengan rumus:

$$
\mathrm{C}=\sum \frac{M_{i} \mathrm{x} f_{i}}{f}
$$

Keterangan: $C=$ persentase penutupan jenis lamun ke- $i, M_{i}=$ persentase titik tengah dari kelas kehadiran jenis lamun ke-i, $f_{i}=$ banyaknya sub petak dimana kelas kehadiran jenis lamun $i$ sama, $\sum f=$ jumlah total frekuensi seluruh penutupan jenis.

\subsubsection{Kerapatan Jenis Lamun}

Kerapatan jenis adalah jumlah individu (tegakan) persatuan luas. Kerapatan masing-masing jenis pada setiap stasiun dihitung dengan menggunakan rumus (Brower et al., 1990).

$D_{i}=\frac{\sum N i}{\mathrm{~A}}$

Keterangan: $D i=$ jumlah individu (tegakan) ke- $i$ per satuan luas $\left(\mathrm{ind} / \mathrm{m}^{2}\right), N_{i}=$ jumlah individu (tegakan) ke- $i$ dalam transek kuadrat (ind), $A=$ luas transek kuadrat $\left(\mathrm{m}^{2}\right)$.

\subsubsection{Indeks Keanekaragaman}

Indeks keanekaragaman digunakan untuk mengukur kelimpahan komunitas berdasarkan jumlah jenis spesies dan jumlah individu dari setiap spesies pada suatu lokasi. Semakin banyak jumlah spesies, maka semakin beragam komunitasnya. Rumus Indeks keanekaragaman Shannon-Wiener (Odum, 1993) yang digunakan adalah:

$\mathrm{H}^{\prime}=\sum_{i=1}^{s} P i \log 2 P i$

Keterangan: $\mathrm{H}^{\prime}=$ indeks keanekaragaman, $P_{i}$ $=$ proporsi jumlah individu spesies ke- $i$ terhadap jumlah individu total $(\mathrm{ni} / \mathrm{N}), \mathrm{N}=$ jumlah total individu semua spesies.

Indeks keanekaragaman digolongkan pada beberapa kriteria, yaitu: $\mathrm{H}^{\prime} \leq 2=$ Keanekaragaman rendah; $2<\mathrm{H}^{\prime} \leq 3=$ Keanekaragaman sedang; $\mathrm{H}^{\prime}>3=$ Keanekaragaman tinggi.

\subsubsection{Indikator Keberadaan Dugong}

Indikator keberadan dugong di lokasi penelitian dinilai secara analisis deskriptif yaitu dengan mengamati keberadaan jejak makan atau feeding trail yang ditinggalkan oleh dugong dan mengaitkan keanekaragaman jenis lamun pada lokasi penelitian dengan preferensi lamun yang menjadi favorit dugong sebagai makanannya (Juraij et al., 2014). 


\subsubsection{Uji ANOVA}

Data tutupan, dan kerapatan lamun antar stasiun dianalisis dengan metode sidik ragam (ANOVA) menggunakan program SPSS (Statistical Program Software System) versi 17. Bila terdapat perbedaan nyata, dilanjutkan dengan uji Duncan dengan selang kepercayaan $95 \%$.

\section{HASIL DAN PEMBAHASAN}

\subsection{Spesies Lamun}

Lamun yang ditemukan di perairan Teluk Lamteng terdiri dari 3 spesies dengan 2 famili, yaitu $C$. serrulata dan Halodule pinifolia (Famili Cymodoceaceae) serta Halophila ovalis (Famili Hydrocharitaceae). Vegetasi lamun di perairan Teluk Lamteng digolongkan dalam tipe vegetasi campuran, dimana komunitas lamun terdiri lebih dari satu spesies lamun. Spesies $H$. pinifolia dan $H$. ovalis dapat ditemukan di semua stasiun pengamatan, kecuali spesies $C$. serrulata yang hanya ditemukan pada stasiun 1 dan 2 . Hal ini diduga karena pengaruh karakteristik kondisi lingkungan tiap stasiun yang berbeda. Pada saat surut, kondisi lamun pada stasiun 1 dan 2 dalam keadaan tenggelam, kecuali pada stasiun 3 dimana ketika surut terendah sebagian lamun $H$. pinifolia terpapar sinar matahari langsung. Menurut Juraij (2014), hanya jenis lamun berukuran kecil yang mampu menahan air diantara daun-daunnya sehingga dapat bertahan pada kondisi tersebut (terpapar saat surut terendah). Spesies lamun $C$. serrulata memiliki ukuran daun yang lebih besar dan kurang mampu menoleransi kondisi kekeringan sehingga tidak ditemukan pada stasiun 3. Kemunculan spesies lamun tiap stasiun dapat dilihat pada Table 1.

Selain itu, hal ini diperkuat dengan karakteristik substrat di stasiun 1 dan 2 berupa pasir berlumpur yang merupakan jenis substrat yang sesuai untuk pertumbuhan lamun jenis $C$. rotundata dan $C$. serrulata (Hemminga \& Duarte, 2000; Russell et al,. 2013; Ow et al., 2016). Sedangkan stasiun 3 memiliki karakteristik substrat lumpur berpasir yang kurang sesuai untuk pertumbuhan lamun spesies $C$. serrulata sehingga tidak ditemukan jenis lamun tersebut pada stasiun 3. Adam et al. (2016) menjelaskan bahwa perbedaan komposisi jenis substrat dapat menyebabkan perbedaan komposisi jenis lamun, selain itu juga dapat mempengaruhi perbedaan kesuburan dan pertumbuhan lamun. Oleh karena itu, perbedaan komposisi ukuran butiran pasir akan menyebabkan perbedaan nutrisi bagi pertumbuhan lamun, serta adanya proses dekomposisi dan mineralisasi yang terjadi di dalam substrat.

\subsection{Faktor Lingkungan Lamun}

Menurut Hemminga \& Duarte (2000), kerapatan jenis lamun dipengaruhi oleh beberapa faktor diantaranya adalah kedalaman, kecerahan, arus air dan tipe substrat. Hasil pengukuran kecerahan perairan Teluk Lamteng bernilai $75-100 \%$ (Table 2), sehingga sangat mendukung proses fotosintesis. Kecerahan perairan sangat penting bagi ekosistem lamun, karena erat kaitannya dengan proses fotosintesis (Nuzapril et al., 2019). Menurut Muchsin et al. (2017), kekeruhan karena suspensi sedimen dapat menghambat penetrasi cahaya ke dalam perairan, dan secara otomatis kondisi ini akan mempengaruhi pertumbuhan

Table 1. The appearance of seagrass species at each station.

\begin{tabular}{lllccc}
\hline Family & Genus & Species & S1 & S2 & S3 \\
\hline Cymodoceaceae & Cymodocea & C. serrulata & + & + & - \\
& Halodule & H. pinifolia & + & + & + \\
Hydrocharitaceae & Halophila & H. ovalis & + & + & + \\
\hline
\end{tabular}

Information: +: There is - : There is not 
dan kehidupan lamun.

Pengukuran kecepatan arus perairan Teluk Lamteng berkisar antara 0,02-0,12 $\mathrm{m} /$ detik (Table 2). Hasil ini sesuai dengan pendapat Koch (2001) untuk mendukung pertumbuhan dan distribusi padang lamun yang sehat diperlukan kecepatan arus yang sedang (0,05-1,00 m/detik). Pada ekosistem lamun, kecepatan arus sangat penting dalam menentukan tingginya produktivitas primer, melalui pencampuran dan penyebaran unsur hara dan gas-gas, serta memindahkan limbah. Berdasarkan Table 2, hasil analisis substrat lamun perairan Teluk Lamteng terdiri dari substrat pasir berlumpur hingga lumpur berpasir. Menurut Koch (2001), hampir semua tipe substrat dapat ditumbuhi lamun, mulai dari substrat berlumpur sampai substrat berbatu. Padang lamun yang luas lebih sering ditemukan di substrat lumpur berpasir yang tebal antara hutan rawa mangrove dan terumbu karang.

Pengukuran suhu perairan Teluk Lamteng berkisar antara $28-29^{\circ} \mathrm{C}$ (Table 2). Dalam hal ini masih dalam batas toleransi lamun. Menurut Collier \& Waycott (2014), kisaran temperatur optimal bagi spesies lamun adalah $28-30^{\circ} \mathrm{C}$. Kemampuan lamun dalam melakukan proses fotosintesis akan menurun dengan tajam apabila temperatur perairan berada di luar kisaran optimal. Pengukuran nilai salinitas perairan Teluk Lamteng berkisar antara 30\%-31\%o (Table 2). Dalam hal ini juga masih merupakan kisaran normal toleransi salinitas. Menurut Olsen et al. (2016), kemampuan lamun dalam menoleransi salinitas berbedabeda, namun sebagian besar memiliki kisaran yang lebar antara $10 \%$-40\%o. Nilai salinitas untuk spesies lamun adalah 35\%o. Xu et al.
(2016) menyatakan bahwa penurunan salinitas menyebabkan laju fotosintesis dan pertumbuhan lamun menurun dan berpengaruh terhadap perkecambahan dan pembentukan bunga lamun.

\subsection{Penutupan Lamun}

H. pinifolia memiliki tutupan paling tinggi diantara spesies lainnya yaitu dengan nilai $67,84 \%$. Selanjutnya diikuti spesies $C$. serrulata sebesar $44,79 \%$ dan tutupan paling rendah adalah spesies $H$. ovalis dengan hanya $2,21 \%$. Hal ini juga sesuai dengan hasil analisis sidik ragam (ANOVA) yang menunjukkan bahwa rata-rata penutupan lamun antar stasiun memberikan pengaruh yang berbeda nyata $(p>0,05)$. Tingginya persentase tutupan lamun $H$. pinifolia dikarenakan menurut Den-Hartog (1970) bahwa $H$. pinifolia merupakan jenis lamun pionir yang akan tumbuh dan berkembang, selanjutnya diikuti dengan munculnya genus Cymodocea dan Halophila. Berdasarkan hasil analisis substrat (Table 2) diketahui bahwa lamun $H$. pinifolia dapat tumbuh di semua stasiun baik pada substrat pasir berlempung hingga lempung berpasir. Menurut Bujang et al. (2016), lamun ini merupakan spesies pionir yang dominan tumbuh dalam lingkungan perairan yang mengalami gangguan atau di lingkungan yang tidak menguntungkan bagi spesies lamun lainnya.

Jika dilihat dari kondisi tutupannya, spesies $H$. pinifolia termasuk dalam kondisi kaya dan sehat karena memiliki tutupan $>60 \%$. Spesies C. serrulata jika dilihat dari kondisi tutupannya termasuk dalam kondisi kurang kaya atau kurang sehat karena me-

Table 2. Analysis of seagrass environmental parameters at each station.

\begin{tabular}{ccccccc}
\hline \multirow{2}{*}{$\begin{array}{c}\text { Study } \\
\text { site }\end{array}$} & \begin{tabular}{c} 
Temperature \\
\cline { 2 - 5 }$\left({ }^{\circ} \mathrm{C}\right)$
\end{tabular} & $\begin{array}{c}\text { Salinity } \\
(\%)\end{array}$ & $\begin{array}{c}\text { Current } \\
(\mathrm{m} / \mathrm{s})\end{array}$ & $\begin{array}{c}\text { Brightness } \\
(\%)\end{array}$ & $\begin{array}{c}\text { Number species } \\
\text { of seagrass }\end{array}$ & Substrate \\
\hline 1 & 28.3 & 30 & 0.02 & 100 & 3 & Loam Sandy \\
2 & 28 & 30.6 & 0.03 & 75 & 3 & Loam Sandy \\
3 & 28 & 30 & 0.12 & 100 & 2 & Sandy loam \\
\hline
\end{tabular}




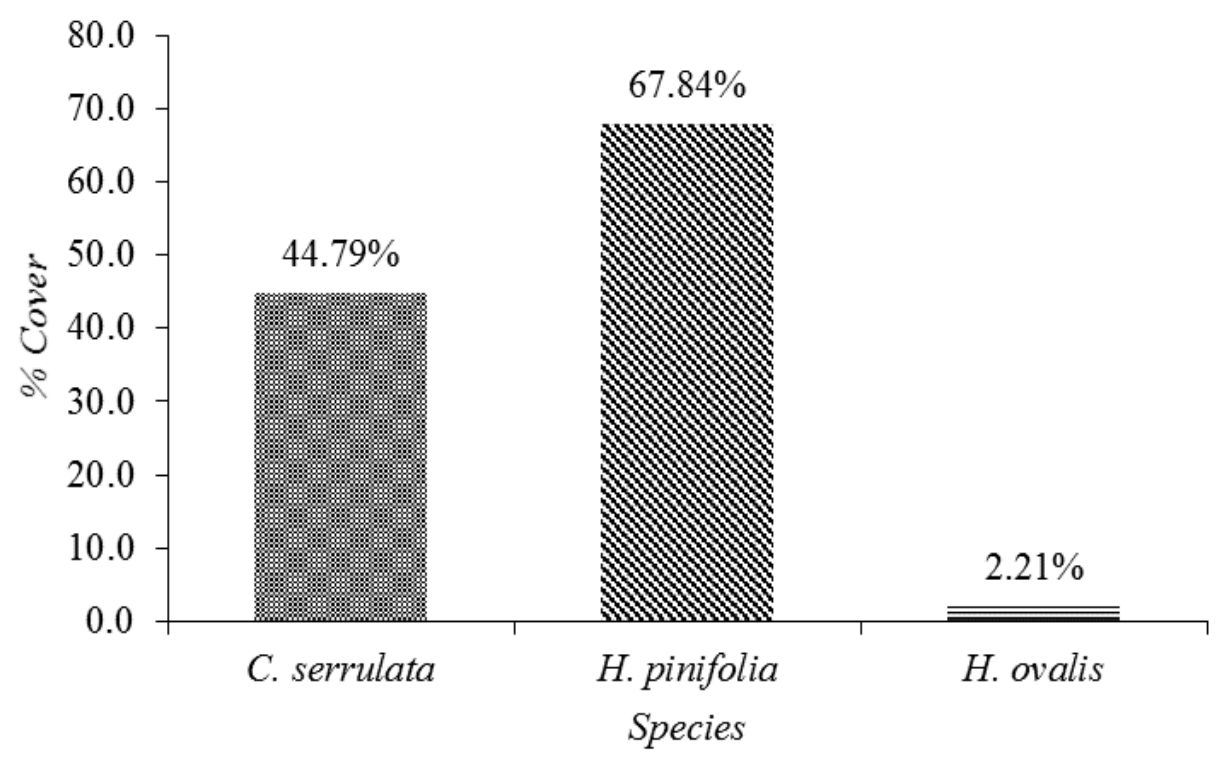

Figure 2. Percentage of seagrass cover in Lamteng Bay waters.

miliki tutupan 44,79\%. Sedangkan spesies lamun $H$. ovalis termasuk dalam kondisi miskin, karena hanya memiliki nilai tutupan lamun $<29,9 \%$. Hal ini menunjukkan bahwa status ekosistem lamun di perairan teluk Lamteng termasuk dalam kondisi miskinbaik dengan tutupan 2,21\%-67,84\% (Keputusan Menteri Negara Lingkungan Hidup No. 200 tahun 2004).

\subsection{Kerapatan Lamun}

Jika dilihat secara keseluruhan pada masing-masing stasiun (Figure 3), spesies $H$. pinifolia memiliki nilai kerapatan yang lebih tinggi dibandingkan dengan spesies $C$. serrulata dan $H$. ovalis. Spesies ini ditemukan tersebar pada semua stasiun pengamatan dengan nilai berkisar antara 55$316 \mathrm{ind} / \mathrm{m}^{2}$. Tingginya kerapatan $H$. pinifolia diduga terkait dengan kondisi substrat Teluk Lamteng yang sesuai dengan habitat lamun tersebut yaitu pasir berlumpur hingga lumpur berpasir. Menurut Lisdawati et al. (2018); Dewi et al. (2018), H. pinifolia umumnya dijumpai pada daerah intertidal dan biasanya tumbuh pada substrat berpasir atau berlumpur.

Hal yang sama juga terjadi pada spesies $C$. serrulata, jenis lamun ini tumbuh pada substrat pasir berlumpur atau pasir dari pecahan karang pada daerah pasang surut. Lamun ini biasa terdapat pada komunitas yang bercampur dengan jenis lamun yang lain (Gangal et al., 2012).

Sebaliknya, spesies $H$. ovalis memiliki nilai kerapatan yang paling rendah dibandingkan dengan kedua spesies lainnya. Namun demikian, spesies ini ditemukan tersebar pada semua stasiun meskipun dalam jumlah yang sedikit. Rendahnya kerapatan $H$. ovalis diduga karena lamun ini merupakan jenis lamun yang menjadi makanan favorit dari $D$. dugon sehingga kemungkinan besar telah dimakan oleh mamalia tersebut. Hal ini terlihat dari sisa gigitan dari $D$. dugon pada pangkal daun $H$. ovalis. Pernyataan ini diperkuat oleh Yamamuro \& Chirapart (2005), dugong menyukai $H$. ovalis karena kandungan gizi dan pertumbuhan yang tinggi.

Berdasarkan hasil analisis sidik ragam (ANOVA), kerapatan jenis lamun antar stasiun tidak memberikan pengaruh yang berbeda nyata $(p>0,05)$. Hal ini diduga karena karakteristik habitat yang secara keseluruhan sama terutama substrat yaitu pasir berlumpur hingga lumpur berpasir. 


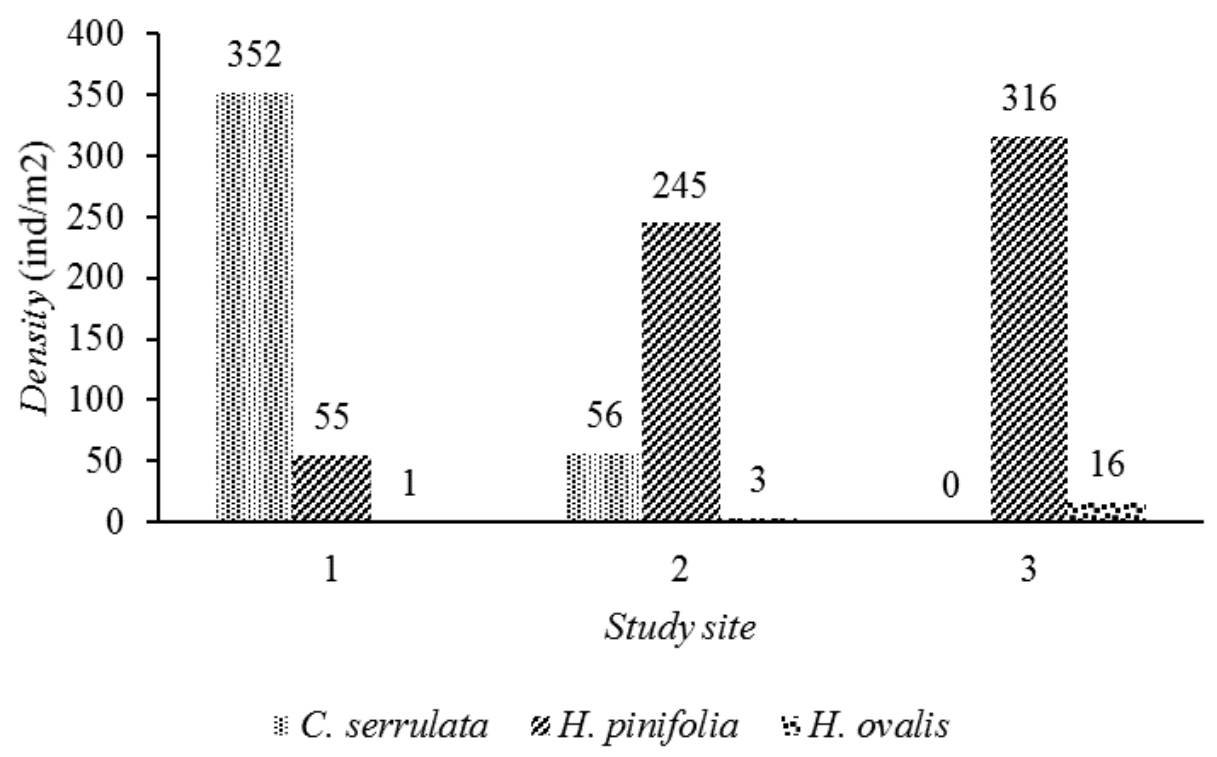

Figure 3. Seagrass density values in the waters of Lamteng Bay.

\subsection{Keanekaragaman Lamun dan Kaitannya Terhadap Sumber Pakan Dugong}

Hasil analisis keanekaragaman lamun dari keseluruhan stasiun dengan menggunakan indeks Shannon-Wienner, perairan Teluk Lamteng memiliki keanekaragaman $H^{\prime}<1$ dengan nilai berkisar antara 0-0,9. Dalam hal ini keanekaragaman tergolong kategori rendah, dikarenakan jumlah spesies yang ditemukan sedikit yaitu hanya 3 spesies. Rendahnya keanekaragaman lamun di Teluk Lamteng diduga karena adanya pengaruh faktor lingkungan seperti substrat. Tipe substrat di Teluk Lamteng adalah pasir berlumpur hingga lumpur berpasir, dimana kandungan pasir dan lumpur atau campuran keduanya berpengaruh terhadap penyerapan nutrien untuk pertumbuhan spesies lamun. Hal ini didukung oleh pernyataan Fahruddin et al. (2017) bahwa dalam proses penyerapan nitrat, substrat pasir kurang baik jika dibandingkan dengan substrat lumpur yang lebih halus teksturnya.

Dugaan lain adalah adanya aktivitas masyarakat sekitar terhadap ekosistem lamun. Menurut Yusuf et al. (2013) nilai indeks keanekaragaman lamun yang rendah bisa disebabkan karena adanya aktivitas masyarakat setempat dalam menangkap ikan.
Adanya aktivitas perahu-perahu nelayan yang mengeruhkan perairan juga dapat mengganggu ekosistem padang lamun sehingga menyebabkan kondisi pertumbuhan lamun terganggu.

Secara visual, keberadaan jalur jejak makan (feeding trail) dugong pada kawasan ekosistem lamun perairan Teluk Lamteng tidak dapat ditemukan. Menurut masyarakat setempat hal ini dikarenakan kemunculan dugong terjadi pada musim timur. Namun demikian dengan melihat hasil keanekaragaman jenis lamun yang ditemukan pada perairan Teluk Lamteng, ketiga jenis yang ditemukan (C. serrulata, $H$. pinifolia dan $H$. ovalis) sesuai dengan jenis lamun yang menjadi makanan kesukaan dugong. Oleh karena itu kawasan ekosistem lamun di daerah ini diduga sering dijadikan area makan (feeding ground) bagi dugong.

\section{KESIMPULAN}

Kesimpulan yang diperoleh berdasarkan hasil penelitian adalah komposisi jenis lamun yang ditemukan di perairan Teluk Lamteng terdiri dari 3 spesies yaitu $C$. serrulata, $H$. pinifolia dan $H$. ovalis. Penutupan lamun tertinggi yaitu spesies $H$. pinifolia $(67,84 \%)$, selanjutnya $C$. serrulata 
(44,79\%) dan paling rendah spesies $H$. ovalis $(2,21 \%)$. Secara keseluruhan stasiun, spesies $H$. pinifolia memiliki nilai kerapatan yang lebih tinggi dibandingkan dengan kedua spesies lamun lainnya dengan nilai berkisar antara 55-316 ind $/ \mathrm{m}^{2}$, dan spesies ini tersebar pada seluruh stasiun pengamatan. Keanekaragaman lamun tergolong rendah dengan nilai berkisar antara 0-0,9. Ketiga spesies lamun yang ditemukan merupakan sumber pakan bagi $D$. dugon yang termasuk dalam kategori preferensi lamun kesukaannya.

\section{DAFTAR PUSTAKA}

Badan Pusat Statistik Kabupaten Aceh. Aceh Besar Dalam Angka 2011. Aceh Besar. 340 p.

Brower, J.E., J.H. Zar, \& C.N. Ende. 1990. Fields and laboratory methods for general Ecology; $3^{\text {rd }}$ edition. Wn. C. Brown Publs, Dubuque. 237 p.

Bujang, J.S., M.H. Zakaria, \& F.T. Short. 2016. Seagrass in malaysia: issues and challenges ahead. In the wetland book. Springer. Netherlands. 199 p. https://doi.org/10.1007/978-94-0076173-5_268-1

Collier, C.J. \& M. Waycott. 2014. Temperature extremes reduce seagrass growth and induce mortality. Marine Pollution Bulletin, 83(2): 483-490. https://doi.org/10.1016/j.marpolbul.2 014.03 .050

Den Hartog, C. 1970. The seagrasses of the world. North Holland Publ., Amsterdam. 275 p.

Dewi, C.S.U., B. Subhan, \& D. Arafat. 2018. Distribusi habitat pakan dugong dan ancamannya di Indonesia. $J$. of Fisheries and Marine Science, 2(2): 128-136. http://doi.org/10.21776/ub.jfmr.2018. 002.02 .9

Duarte, C.M., H. Kennedy, N. Marbà, \& I. Hendriks. 2013. Assessing the capacity of seagrass meadows for carbon burial: current limitations and future strategies. Ocean and Coastal Management, 83: 32-38. https://doi.org/10.1016/j.ocecoaman.2 011.09.001

English, S., C. Wilkinson, \& V. Baker. 1997. Survey manual for tropical marine resources. (S. English, C. Wilkinson, dan V. Baker, Eds.). Australian Institute of Marine Science. Townsville, Austrlia. 390 p.

Fahruddin, M., F. Yulianda, \& I. Setyobudiandi. 2017. Kerapatan dan penutupan ekosistem lamun di pesisir Desa Bahoi, Sulawesi Utara. J. Ilmu dan Teknologi Kelautan Tropis, 9(1): 375-384. https://doi.org/10.29244/jitkt.v9i1.17 952

Gangal, M., R. Arthur, \& T. Alcoverro. 2012. Structure and dynamics of south east indian seagrass meadows across a sediment gradient. Aquatic Botany, 98(1): 34-39. https://doi.org/10.1016/j.aquabot.201 1.12.006

Hashim, M., S. Ito, S. Numata, T. Hosaka, M.S. Hossain, S. Misbari, \& S. Ahmad. 2017. Using fisher knowledge, mapping population, habitat suitability and risk for the conservation of dugongs in Johor Straits of Malaysia. Marine Policy, 78: 18-25. https://doi.org/10.1016/j.marpol.2017. 01.002

Hemminga, M.A. \& C.M. Duarte. 2000. Seagrass ecology. Cambridge University Press. England. 298 p. https://doi.org/10.1017/cbo97805115 25551

Hernawan, U.E., N.D.M. Sjafrie, I.H. Supriyadi, Suyarso, M.Y. Iswari, K. Anggraini, \& Rahmat. 2017. Status padang lamun Indonesia 2017. Pusat Penelitian Oseanografi-LIPI. Jakarta. $23 \mathrm{p}$. 
Muchsin, I., M.M. Kamal, \& Y. Wardiatno. 2017. Kerusakan lamun (seagrass) dan rumusan konservasinya di Tanjung Luar Lombok Timur. $J$. Biologi Tropis, 17(2): 69-80. https://doi.org/10.29303/jbt.v17i2.549

Juraij, D.G. Bengen \& M. Kawaroe. 2014. Keanekaragaman jenis lamun sebagai sumber pakan Dugong dugon pada Desa Busung Bintan Utara, Kepulauan Riau. Omni-Akuatika, 13(19): 24-32. http://doi.org/10.20884/1.oa.2014.10. 2.19

Koch, E.W. 2001. Beyond light: physical, geological, and geochemical parameters as possible submersed aquatic vegetation habitat requirements. Estuaries, 24(1): 1-17. https://doi.org/10.2307/1352808

Kuo, J. 2007. New monoecious seagrass of halophila sulawesii (hydrocharitaceae) from Indonesia. Aquatic Botany, 87(2): 171-175.

https://doi.org/10.1016/j.aquabot.200 7.04.006

Lisdawati, L., S.W. Ahmad, \& L. Siwi. 2019. Studi biomassa lamun (Enhalus acoroides 1.) dan (halodule pinifolia) berdasarkan kedalaman air laut di Pantai Desa Tanjung Tiram Sulawesi Tenggara. BioWallacea : J. Penelitian Biologi, 5(2): 56-67.

http://doi.org/10.33772/biowallacea.v $5 \mathrm{i} 2.5878$

Nordlund, L.M., E.L. Jackson, M. Nakaoka, J. Samper-Villarreal, P. BecaCarretero, \& J.C. Creed. 2018. Seagrass ecosystem services - what's next?. Marine Pollution bulletin, 134: 145-151.

https://doi.org/10.1016/j.marpolbul.2 017.09.014

Nuzapril, M., S.B. Susilo, \& J.P. Panjaitan. 2019. Sebaran produktivitas primer kaitannya dengan kondisi kualitas air di perairan Karimunjawa. $J$. Segara, 15(1): 9-17. https://doi.org/10.15578/segara.v15i1. 7559

Odum, E.P. 1993. Fundamental of ecology. Toppan Company, Ltd. New York. $574 \mathrm{p}$.

Olsen, J.L., P. Rouzé, B. Verhelst, Y.C. Lin, T. Bayer, J. Collen, \& Y. Van De Peer. 2016. The genome of the seagrass zostera marina reveals angiosperm adaptation to the sea. Nature, 530(7590): 331-335. https://doi.org/10.1038/nature16548

Ow, Y.X., S. Uthicke, \& C.J. Collier. 2016. Light levels affect carbon utilisation in tropical seagrass under ocean acidification. PLOS ONE, 11(3): e0150352.

https://doi.org/10.1371/journal.pone.0 150352

Russell, B.D., S.D. Connell, S. Uthicke, N. Muehllehner, K. E. Fabricius, \& J. Hall-Spencer. 2013. Future seagrass beds: can increased productivity lead to increased carbon storage? Marine Pollution Bulletin, 73(2): 463-469.

https://doi.org/10.1016/j.marpolbul.2 013.01.031

Saito, Y. \& S. Atobe. 1970. Phytosociological study of intertidal marine alga. i. usujuri benten-jima, hokkaido. Bulletin of the Faculty of Fisheries, Hokkaido University. Japan. 21: 37-69.

Salim, D., Y. Yuliyanto, \& B. Baharuddin. 2017. Karakteristik parameter oseanografi fisika-kimia perairan Pulau Kerumputan, Kabupaten Kotabaru Kalimantan Selatan. $J$. Enggano, 2(2): 218-228. https://doi.org/10.31186/jenggano.2.2 .218-228

Tol, S.J., R.G. Coles, \& B.C. Congdon. 2016. Dugong dugon feeding in tropical australian seagrass meadows: Implications for conservation planning. PeerJ, 4: e2194.

https://doi.org/10.7717/peerj.2194 
Unsworth, R.K.F., L.J.McKenzie， C.J. Collier, L.C. Cullen-Unsworth, C.M. Duarte, J.S. Eklöf, \& L.M. Nordlund. 2019. Global challenges for seagrass conservation. Ambio, 48(8): 801-815. https://doi.org/10.1007/s13280-0181115-y

Van Katwijk, M.M., A. Thorhaug, N. Marbà, R.J. Orth, C.M. Duarte, G.A. Kendrick, \& J.J. Verduin. 2016. Global analysis of seagrass restoration: the importance of largescale planting. $J$. of Applied Ecology, 53(2): 567-578. https://doi.org/10.1111/13652664.12562

$\mathrm{Xu}$, S., Y. Zhou, P. Wang, F. Wang, X. Zhang, \& R. Gu. 2016. Salinity and temperature significantly influence seed germination, seedling establishment, and seedling growth of seagrass Zostera marina L. Peer J., 4: e2697. https://doi.org/10.7717/peerj.2697

Yamamuro, M. \& A. Chirapart. 2005. Quality of the seagrass Halophila ovalis on a Thai intertidal flat as food for the dugong. $J$. of Oceanography, 61(1): 83-186. https://doi.org/10.1007/s10872-0050030-6

Yunitha, A., Y. Wardiatno, \& F. Yulianda. 2014. Diameter substrat dan jenis lamun di pesisir Bahoi Minahasa Utara: sebuah analisis korelasi. $J$. Ilmu Pertanian Indonesia (JIPI), 19(3): 130-135.

http://journal.ipb.ac.id/index.php/JIPI /article/view/9146/7191

Yusuf, M., Y. Koniyo, \& C. Panigoro. 2013. Keanekaragaman lamun di perairan sekitar Pulau Dudepo Kecamatan Anggrek Kabupaten Gorontalo Utara. J. Ilmiah Perikanan dan Kelautan, (1)1: 18-25.

http://ejurnal.ung.ac.id/index.php/nik e/article/view/1212/962

Received : :06 August 2019

Reviewed :07 November 2019

Accepted :01 March 2020 
